УДК 37.01+159.9

DOI: https://doi.org/10.54662/veresen.2.2021.10

Ірина Хозраткулова,

ORCID iD 0000-0002-4841-9359

кандидат педагогічних наук, доцент,

доиент кафедри педагогіки, психології та менеджменту освіти

Миколаӥвський обласний інститут

післядипломної педагогічної освіти

вул. Адміральська, 4-а, 54001, м. Миколаїв, Україна

iryna.khozratkulova@moippo.mk.ua

\title{
АНТИЦИПАЦІЯ ЯК ОДНА 3 УМОВ ПРОГНОЗУВАННЯ САМОРОЗВИТКУ ПЕДАГОГІВ
}

У статті акиентуємо увагу на необхідності розвитку антиципаційної спроможності як одного з основних чинників, щуо впливає на прочес саморозвитку педагогів. Ситуацію саморозвитку розглянуто як стресову. Феномен стресостійкості представлено як здатність особистості справлятися з труднощами. Зазначено роль стресостійкості для саморозвитку і самореалізачї̈ педагогічних кадрів. Охарактеризовано проблему низького рівня стресостійкості педагогів як серйозну перешкоду на шляху професійної та особистісної мотивачії до саморозвитку.

Приділено увагу важливості розвитку анитищипаційних схем, які допомагають активно пізнати навколишню дійсність, розуміти нову інформацію.

Автор статті спирається на концептуальні положення позитивної психотерапії, яка виходить із приничипу здатності людини до саморозвитку і гармонії. Для успішного саморозвитку особистості важливо враховувати, щуо задоволення потреби викликає позитивну емоцію, надає енергї для активізації вольового зусилля.

У статті зроблена спроба знайти корелячійні зв'язки між рівнем стресостійкості педагога та сформованою спроможністю до антиципації. Охарактеризовано вилив емочійної стабільності на процес мотивації до саморозвитку та особливості прогнозування подальшого професійного вдосконалення.

Ключові слова: антищипація; педагог; прогнозування; самомотивачія; самопізнання; саморозвиток; стресостійкість.

(C) Хозраткулова I. А., 2021

Вступ. Неможливе вивчення проблеми саморозвитку поза вивченням явищ передбачення, прогнозування, екстраполяції, випереджального відображення. Характер імовірнісного прогнозування пов'язаний iз діяльністю суб'єкта, із його потребами, цілями, із його можливостями впливати на середовище і на своє становище в ньому.

Важливим є вивчення антиципації в діяльності людини, тобто здатності використовувати накопичений індивідуальний досвід для ймовірнісного прогнозування майбутньої ситуації в цілях підготовки ефективних дій до власного саморозвитку.

Дослідження саморозвитку і визначення ролі антиципації може якісно вплинути на ефективність планування професійного зростання.

Нині залишається відкритим й актуальним питання самомотивації педагога у стані емоційної нестабільності (стресі). У контексті заявленої проблематики ми намагалися проаналізувати процес саморозвитку та визначити роль антиципації у професійному зростанні.

Дані статистики здебільшого свідчать про не завжди позитивний емоційний стан педагогічних кадрів. Виникає питан- 
ня: у ситуації хронічного стресу, які стратегії обирає педагог для планування, яким бачить майбутнє? Антиципаційна спроможність людини багато в чому визначає готовність до змін і це може відбиватися i на плануванні майбутнього і на бажанні вдосконалюватися.

Ситуація 3 пандемією ускладнює життя всього людства, а педагогічна діяльність, яка сама по собі вважається енергозатратною і «душевно небезпечною», узагалі перебуває у групі ризику. Перед педагогічними кадрами стоїть важлива задача переходу на нові дистанційні форми навчання за короткий проміжок часу. Також можуть додатися проблеми в особистих стосунках, сімейному оточенні, проблеми зі здоров'ям тощо. Ситуацію саморозвитку можна також розглядати як стресову. Нині багато педагогічних кадрів абсолютно не готові до змін і таку якість, як толерантність до невизначеності, потрібно випрацьовувати роками. Це одна $з$ причин низького рівня самомотивації до навчання серед педагогів.

Аналіз наукових досліджень і публікацій. Уперше гностична цінність поняття антиципація з'явилась у працях В. Вундта. Проблему антиципації досліджували вітчизняні та зарубіжні вчені. У статті С. Н. Перегуди (Перегуда С. Н., 2015) розмежовуються основні сучасні підходи до розуміння антиципації, так умовно можна виділити когнітивно-поведінковий (У. Найссер (Найссер У.), О. О. Сергієнко (Сергиенко Е. А., 2006) та ін.), психофізіологічний (П. К. Анохін (Анохин П. К., 1998), М. О. Бернштейн (Бернштейн Н. А., 1997) та ін.), діяльнісний (Б. Ф. Ломов (Ломов Б. Ф., Сурков Е. Н., 1980), Н.В.Толстошеїна (Толстошеина Н. В., 2002), Л. О. Регуш (Регуш Л. А., 2003) та ін.), ситуаційний (Р. Нісбетт, Л. Росс (Росс Л., Нисбетт Р., 2000) та ін.), клінічний (В. Д. Менделевич (Менделевич В. Д., Граница А. С., 2013; Менделевич В. Д., 1998), Н . Бережна (Бережная Н. И., 2013), I. М. Фейгенберг (Фейгенберг И. М., 1977), та ін.) підходи. Сучасна психологія розглядає поняття антиципації як здатність людини діяти і приймати ті чи інші рішення
3 певним тимчасово просторовим випередженням. Антиципація - це можливість тією чи іншою мірою передбачати розвиток подій, явищ, результати дій.

На думку А. В. Брушлінського (Брушлинский А. В., Воявикова М. И., Дружинина В. Н., 2000), є відчутний зв'язок між саморегуляцією та формами мислення, що передбачають події.

Анитиципаційні схеми допомагають активно пізнати навколишню дійсність, розуміти нову інформацію, інтегруватись і модифікувати схеми, що передбачають дійсність. Ідеї програмованих дій, вірогідності прогнозування та випереджального відображення напряму пов'язані з готовністю до змін і мотивацією до саморозвитку. У поведінці та діяльності антиципація «забезпечує формування мети, планує і програмує поведінку».

Наукові дослідження Н. В. Толстошеїної визначають настановчі тенденції, що передують розвивальній діяльності, виникають як проміжна ланка між потребою і можливістю її задоволення (Толстошеина Н. В., 2002).

За даними досліджень Н. П. Ничипоренко, відомо, що низькі показники антиципаційної спроможності вказують на можливі порушення в системі психічної адаптації особистості (Ничипоренко Н. П., 2007, c. 123-130).

У роботах Т. В. Корнілової зазначено, що успішність прогнозування найвища, коли в рамках антиципації працюють і логіка, і інтуїція (Корнилова Т. В., 2013, с. 90).

Дані досліджень демонструють, що при різних емоційних розладах спостерігаємо порушення процесів антиципації. Можемо припустити, що у педагога, який перебуває у стресовому стані, порушується механізм антиципації, у нього виникають труднощі зі здатністю передбачати події, у цьому контексті нас цікавить динаміка процесу самовдосконалення.

Мета статті - акцент уваги на необхідності розвитку антиципаційної спроможності, яка впливає на процес саморозвитку педагогів в умовах хронічного стресу. 
Відповідно до мети визначено такі завдання: проаналізувати поняття антиципації та виявити взаємозв'язок між поняттями стресостійкість особистості та антиципаційна спроможність.

Виклад основного матеріалу. Педагоги здебільшого є перфекціоністами 3 високим рівнем відповідальності, які намагаються поєднувати безліч справ і людей в особистому житті і професійній діяльності, і як наслідок - хронічний стрес. Дослідниця Н. О. Рибакова наголошує: «емоційна компетентність $є$ значущою складовою професійної компетентності педагога в цілому, тому що дозволяє подолати багато психологічно зумовлених небажаних ефектів його насиченої праці» (Рыбакова Н. А., 2019, c. 195). Наші дослідження і власні скарги педагогів свідчать і про те, що останні не вміють казати «ні», особливо це стосується молодих педагогів. Зрозуміло, що минулий досвід і наявна ситуація дають підставу для створення гіпотез про майбутнє 3 деякою долею ймовірності виникнення.

Ми провели експрес-опитування серед учителів, вихователів шкіл-інтернатів та вихователів закладів дошкільної освіти. На питання: «Чи готові Ви до саморозвиткy?» відповіли: «Так» 65 \% педагогів, не визначаючи причин неготовності. А на питання: «Чи відчуваєте потребу у професійному зростанні?» «Так» відповіла тільки половина опитуваних.

Приблизно така ж тенденція спостерігалася за результатами проведеної діагностики рівня саморозвитку у професійно-педагогічній діяльності Л. Бєрєжнової. Тест «Рефлексія на саморозвиток» містить 18 питань та три варіанти відповіді на кожне (Бережная Н. И., Фетискин Н. П., Козлов В. В., Мануйлов Г. М., 2002, с. 286). За результатами тестування за шкалою «Прагнення до саморозвитку» середній рівень визначено у $60 \%$ учителів, $21 \%$ мають низький і нижче за середній рівні, вище за середній та високий - $16 \%$, та $3 \%$ - дуже високий, дуже низького показника до саморозвитку виявлено не було.

Концептуальні положення теорії
К. Роджерса позначають прагнення особистості до актуалізації як уродженої тенденції «розвивати всі свої здібності, щоб зберегти і розвинути особистість». На думку К. Роджерса, ця тенденція, що актуалізує, вибіркова, вона спрямована на ті аспекти середовища, які обіцяють конструктивний рух особистості до завершеності і цілісності (Роджерс К., 2016, с. 115).

Небезпека полягає в тому, що багато вчителів перебувають у стані хронічної образи на учнів, їхніх батьків, колег та адміністрації. Вони впевнені в тому, що в суспільстві професія педагога втратила авторитет і значущість. Уважають, що віддають більше, ніж отримують. А що вчителі мають отримати? Яким має бути зворотний зв'язок із оточенням? Можливо, саме підтримка оточення $\epsilon$ важливим енергетичним наповнювачем для натхнення? Так чи інакше такі педагоги перебувають у стані емоційної дисгармонії, підвищеної тривожності та психологічного напруження.

Очевидно, що в такій неблагополучній ситуації ускладнюється процес саморозвитку. На шляху вдосконалення з'являються помилки, виникають труднощі, але реакція на це може бути абсолютно різною і залежить вона від багатьох факторів: локус контролю, типу мислення, упевненості, темпераменту, досвіду, установок та цінностей. Виходячи з вищезазначеного, актуальним і важливим завданням для практичних психологів системи освіти вважаємо супровід педагогічних кадрів, розвиток їхньої стресостійкості.

За визначенням Н. I. Бережної, стресостійкість - інтегративна властивість особистості, що характеризується такою взаємодією емоційних, вольових, інтелектуальних і мотиваційних компонентів психічної діяльності людини, які забезпечують оптимальне успішне досягнення мети діяльності в складній емотивній обстановці (Бережная Н. И., 2013, с. 86). Отже, аналізуючи багато варіантів розуміння поняття стресостійкісті, науковці сходяться у визначенні, що це здатність справлятися 3 тими вимогами, які людині висувають. 
Якщо проаналізувати різні наукові підходи, то виявиться, що єдиного визначення стресу немає: кожна з теорій трактує його по-своєму. Психофізіолог Г. Сельє (1936) одним із перших визначав стрес як неспецифічну відповідь організму на будь-яку висунену до нього вимогу, насамперед таку, що характеризується емоційними афектами. Американський психолог Р. Лазарус (1966) вивчав уплив когнітивної оцінки ситуації загрози на формування стресової реакції, i йому належить таке визначення: стрес - це стан або почуття, яке відчуває людина, коли усвідомлює, що «вимоги перевищують особисті і соціальні ресурси, які вона здатна мобілізувати».

Нині вже доведено багатьма вченими, що в ситуації стресу людина втрачає рівновагу, стає емоційно нестабільною, особливо коли причин для напруження $\epsilon$ більше, ніж одна, і хронічний стрес може призвести до серйозних проблем із психічним здоров'ям. Нормою для стресостійкої особистості є розуміння, що зміни в житті важливіші за стабільність; вона впевнена, що сама керує своїм життям, і щиро цікавиться навколишньою дійсністю. Така людина може будувати процес прогнозування 3 багатьма варіантами, бути гнучкою, уміло використовуючи попередній досвід. В. Д. Менделевич уважав, що одним із принципів неврозостійкості особистості $€$ принцип випрацювання стратегії «антиципувального совладання», відмова від «передбаченого суму», натомість «передбаченої радості» (Менделевич В. Д., Граница А. С., 2013, с. 23).

Ми провели дослідження, у якому порівняли показники стресостійкості з можливістю прогнозувати майбутнє.

Характеристика досліджуваної групи. У дослідженні з 2019 до 2021 рр. узяли участь 144 педагоги, із них високий рівень стресостійкості визначався у 82 педагогів (група «ВС»), 62 особи під час опитування продемонстрували низький рівень стресостійкості (група «НС»). Вік досліджуваних складав від 27 до 58 років, із них 119 осіб були жінки, стаж педагогічної ді- яльності не враховувався.

Методи дослідження. Учасникам експерименту було запропоновано пройти письмове опитування за трьома методиками. Важливо зазначити, що діагностування проводилось як під час безпосереднього контакту, так і в режимі онлайн-опитування.

1. Для оцінки стресостійкості ми використовували експрес-методику «Перцептивна оцінка типу стресостійкості» (Фетискин Н. П., 2002, с. 116), результати відповідей на 20 питань поділили досліджуваних на дві підгрупи - «людина типу А» характеризувалася низьким рівнем стресостійкості та «людина типу Б» була визначена як стресостійка. Також ми застосували Шкалу стресостійкості і соціальної адаптації Холма і Раге (Фетискин Н. П., Козлов В. В., Мануйлов Г. М., 2002, c. 143), у якій перелічені психотравмувальні ситуації за останні два роки, але підраховувалося середнє арифметичне за рік. У результаті інтерпретації здобутих даних за двома методиками ми виявили осіб, у яких збігалися діагностичні показники високого або низького рівнів стресостійкості. У такий спосіб ми сформували дві групи піддослідних. У першу групу увійшли педагоги - «людина за типом Б» із високим рівнем стресостійкості, та ті, які набрали менше 200 балів за рівнем стресостійкості за шкалою Холмса - Раге, яку в експерименті позначили як групу «ВС». Другу групу склали педагоги «людина 3 типом А» із низьким рівнем стресостійкості та за результатами суми балів за Шкалою Холмса - Раге опитувані набрали 300 і більше. Таким чином було сформовано групу «НС».

2. Для виявлення антиципаційної спроможності ми використали тест антиципаційної спроможності (прогностичної компетентності) В. Д. Менделевича (Менделевич В. Д., 1998, с. 492). Цей тест складається 381 питання, кожне питання оцінюється за п'ятибальною шкалою від одного (не згоден) до п'яти (абсолютно згоден). Результати підраховувалися за чотирма шкалами: загальна антиципацій- 
на спроможність, особистісно-ситуативна, просторова (рухова) і тимчасова антиципаційна спроможність.

Статистичний аналіз проводили за програмою STATISTICA forWindows, Stat. Soft, Inc., 1984-2001. Групи були перевірені за допомогою коефіцієнта Шапіро-Уїлкі, і розподіл виявився ненормальним. Тому для оцінки відмінностей використовувався U-критерій Манна-Уїтні, а кореляція підраховувалася за допомогою коефіцієнта кореляції Спірмена. Досліджувався характер зв'язків між параметрами стресостійкості й антиципації, а також відмінності стресостійкості й антиципації між різними групами піддослідних.

Результати та висновки дослідження. Були виявлені достовірні відмінності у вияві стресостійкості між групою «ВС» i «НС» i антиципаційною спроможністю $(\mathrm{p}=0,0365)$. Була визначена достовірна пряма кореляція між високим рівнем стресостійкості і антиципаційною спроможністю $(\mathrm{p}=0,403)$. Отже, у ході дослідження виявлені достовірні відмінності в антиципаційній спроможності між групою «ВС» і «НС», що свідчить про різний розвиток можливостей прогнозування майбутнього у стресостійких осіб і в осіб із низьким рівнем стресостійкості. Особистість, яка схильна до стресових розладів, вимикає небажані події, тобто демонструє антиципаційну неспроможність. Витривалість до напружень, стресостійкість особистості пов'язані з антиципацією. Визначено прямі кореляції між антиципаційною здатністю і високою стресостійкістю.

Клінічний психолог В. Д. Менделевич (1988-2013) визначає, що в умовах розходження прогнозу і при крайньому варіанті емоційних переживань (образи, розчарування, розгубленості), пов'язаних із цією прогностичною помилкою, людина може не використовувати потенційних можливостей совладання з ситуацією і захворіти неврозом (Менделевич В. Д., Граница А. С., 2013, c. 42).

Позитивна психотерапія виходить 3 принципу здатності людини до саморозвит- ку і гармонії. Прихильники цього напряму впевнені, що природними для людини $\epsilon$ розширення життєвих цілей, виявлення резервів і нових можливостей для здолання труднощів.

У теорії самодетермінації Е. Десі (2000) досліджуються процеси внутрішньої мотивації, висувається проблема власної активності людини, іiі здібності самостійного вибору напряму саморозвитку. Дійсно, щасливою $є$ та людина, якій робота дає радість, задоволення, сприяє особистісному зростанню і самореалізації. А нещасною може стати людина, для якої обрана справа є джерелом роздратування, нудьги, приниження і відчуття безпорадності.

У процесі самоаналізу людина розбирається у своїх потребах, нереалізованих бажаннях та можливостях змінити проблемну ситуацію. Але саме по собі усвідомлення необхідності змін не $є$ достатньою умовою для реальної зміни, потрібне вольове поведінкове зусилля. У ланцюжку вольового акту за прийняттям рішення йде його виконання. Наукові дослідження і життєві спостереження доводять, що це найскладніший етап вольової дії.

Ученими доведено: коли не задовольняються особистісні потреби та не досягається бажане, одразу виникає емоція. Тому для саморозвитку особистості важливо враховувати, що задоволення потреби викликає позитивну емоцію та сприяє дії, наприклад, стимулом для навчання є емоція інтересу; пізнавальна діяльність може бути викликана зацікавленістю. Для успішного самовдосконалення особистості усвідомлена саморегуляція в доланні зовнішніх і внутрішніх перешкод, емоційна витримка - необхідна навичка.

Характер переживань зумовлений суб'єктивним ставленням до потреби. Виникає питання: «Потреба в саморозвитку для педагогів є настільки значущою, що спонукає до дій і спрямовує всі ресурси для досягнення бажаного результату?» На наш погляд, найважливішим є розуміння взаємозалежності волі як психічного процесу 3 емоційним станом. Безумовно, є люди, 
які здатні діяти плідно і творити на фоні страждання, їм потрібно кожного дня долати самих себе, життя для них - це постійна боротьба. Зараз говорять: «Щоб досягти чогось, потрібно «вийти з зони комфорту». На наш погляд, у процесі цілепокладання усе ж більш психологічно благополучними вважаються дії, спрямовані не на «вихід...», а на «розширення зони комфорту». Діапазон саморозвитку в стані психологічного напруження як боротьба з самим собою, так би мовити спартанського, аскетичного життя має бути якомога меншим.

У сучасного педагога має сформуватися навичка саморозвитку через досягнення бажаного результату в навчанні на фоні позитивних емоцій, у стані задоволення, коли особистість не витрачає ресурси, а навпаки, у процесі саморозвитку наповнюється енергією. Це вміння робити життя легким і приємним.

Для того, щоб стати суб'єктом самоперетворення, педагог має прийняти себе, бути автентичним, що дозволить йому позбутися внутрішніх суперечностей, допоможе знайти конструктивні способи впливу на себе й ефективну взаємодію з навколишнім світом. У такому стані виникає оптимізм, бажання працювати, людина не відчуває тривоги, емоційного напруження і виснаження. Безумовно, ми не претендуємо на таку однозначність у рішенні проблеми саморозвитку, у різних людей процес самовизначення, самореалізації в різні періоди життя відбувається по-різному і встановлювати норму тут неможливо, але ми зазначили тенденцію, яку можна було б урахувати на шляху самовдосконалення особистості.

Свідома організація свого професійного й особистісного саморозвитку має відбуватись у гармонії і емоційній стабільності. У рамках психології самореалізації упор робиться на відпрацювання психологічної стратегії - максимально використовувати в житті власний особистісний потенціал. Характеризуючи психологічні особливості людини в стані хронічного стресу, звертаємо увагу на труднощі, а часом і неможливість передбачити, прогно- зувати весь можливий ланцюг наступних етапів діяльності.

Для успішного саморозвитку потрібні знання себе, своїх можливостей, розуміння своїх сильних сторін та наявність психологічних ресурсів. А головне - прийняти себе як людину, яка робить помилки, можливо, недосконала, і саме це формує базу для бажання бути краще, розвиватись і вдосконалюватись у будь-якому віці з будь-яким стажем професійної діяльності. Вимога сьогодення - навчатися протягом життя. А також - навчитися жити з собою у злагоді, щоб мріяти і планувати.

Механізм адекватного сприйняття труднощів спрацює в разі здатності особистості передбачати розвиток подій та приймати будь-які результати запланованих дій. Педагог за рахунок здатності діяти і приймати ті чи інші рішення з певним тимчасово просторовим випередженням не «виходить із зони комфорту», а «розширює iii», він володіє навичками вмілого користування внутрішніми важелями. Для того, щоб вольовий порив діяв без шкоди для здоров'я, педагогу потрібно знати, що професія вчителя - це велика місія, а справжня велика мета - це бути щасливим у профеciï.

У системі післядипломної освіти важливо розглянути антиципацію як регулятор соціальних взаємозв' язків. Ми згодні 3 ученими О. О. Сергієнко (Сергиенко Е. А., 2006), Н. В. Толстошеїною (Толстошеина Н. В., 2002), що доцільно виділяти не тільки когнітивно-регулятивний аспект антиципації, а й комунікативний. Важливо розглядати вплив соціального фактору, що дозволяє виконувати нестандартні завдання в часі і просторі, випереджаючи планувати і координувати дії разом 3 іншими на основі плану. Особистість послуговується не тільки власним досвідом, а й знаннями, апробованими власним оточенням.

Висновки. Витривалість до напружень, стресостійкість особистості напряму повязані з антиципацією. Стан постійного впливу стресорів на особистість педагога впливає на антиципаційну спроможність, 
що так само негативно відгукується на процес самопізнання особистості, особливо на формування внутрішньої мотивації до саморозвитку.

Перспективою подальших дослі- джень може бути вивчення особливостей кореляційних зв'язків між показниками антиципації, особливостями спілкування i досягнення цілей у командній діяльності.

\section{ЛІТЕРАТУРА}

1. Анохин П. К. Избранные труды: Кибернетика функциональных систем / под ред. К. В. Судакова. - М. : Медицина, 1998. - 400 с.

2. Бережная Н. И. Стрессоустойчивость оперативных сотрудников таможенных органов / Н. И. Бережная // Материалы III Всероссийского съезда психологов (25-28 июня 2013 г): в 8 т. Т. 1. - СПб., 2013.

3. Бернштейн Н. А. Очерки по физиологии движений и физиологии активности / Н. А. Бернштейн // Биомеханика и физиология движений. - М. : Издательство «Институт практической психологии»; Воронеж : НПО «Модэк», 1997. - С. 300-478.

4. Корнилова Т. В. Психология неопределенности: единство интеллектуально-личностной регуляции решений и выборов/ Т. В. Корнилова // Психологический журнал. 2013. - 34(3). - C. 89-100.

5. Ломов Б. Ф., Сурков Е. Н. Антиципация в структуре деятельности / Б. Ф. Ломов, Е. Н. Сурков. - М. : Наука, 1980. - 279 с.

6. Менделевич В. Д., Граница А. С. Прогнозирование будущего и механизмы неврогенеза / В. Д. Менделевич, А. С. Граница // Неврологический вестник. - 2013. - T. XLV, вып. 4. - С. 42.

7. Менделевич В. Д. Клиническая и медицинская психология. Практическое руководство / В. Д. Менделевич. - М. : «МЕДпресс», 1998. - 592 с.

8. Найссер У. Познание и реальность / У. Найссер. - М. : «Прогресс», 1981. - 225 с.

9. Ничипоренко Н. П. Прогностическая компетентность в системе личностных свойств / Н. П. Ничипоренко // Вопросы психологии. - 2007. - № 2. - С. 123-130.

10. Перегуда С. Н. Нейропсихологический уровень исследования антиципации в современной психологии / С. Н. Перегуда // Клиническая и медицинская психология: исследования, обучение, практика: электрон. науч. журн. - 2015. - N 4 (10) [Электронный pecypc]. - Режим доступу: http://medpsy.ru/climp

11. Проблема субъекта в психологической науке: монография / [А. В. Брушлинский, М. И. Воявикова, В. Н. Дружинин]. - М. : Издательство «Академический проект», 2000. $-320 \mathrm{c}$.

12. Регуш Л. А. Психология прогнозирования: успехи в познании будущего / Л. А. Регуш. - СПб. : Речь, 2003. - 352 с.

13. Роджерс К. Становление личности. Взгляд на психотерапию / К. Роджерс. - М. : Институт общегуманитарных исследований, 2016. - 240 с.

14. Росс Л., Нисбетт Р. Человек и ситуация. Уроки социальной психологии / пер. с англ. В. В. Румынского; под ред. Е. Н. Емельянова, В. С. Магуна. - М. : Аспект Пресс, 2000. -429 c.

15. Рыбакова Н. А. Эмоциональная компетентность педагога: сущностная характеристика / Н. А. Рыбакова // Педагогика. Вопросы теории и практики. Тамбов : Грамота, 2019. T. 4. - С. 190-195. [Електронний ресурс]. - Режим доступу: DOI:https://doi. org/10.30853/pedaqoqy.2019.4.35

16. Сергиенко Е. А. Раннее когнитивное развитие: новый взгляд / Е. А. Сергиенко. - М. : Изд-во «Институт психологии РАН», 2006. - 466 с.

17. Толстошеина Н. В. Антиципация как одно из условий прогнозирования, выбора и регуляции будущей деятельности / Н. В. Толстошеина // Электронный журнал Гаудеамус. - 2002. - № 2 (2). - Режим доступу: https://cyberleninka.ru/article/n/antitsipatsiya-kak- 
odno-iz-usloviy-prognozirovaniya-vybora-i-regulyatsii-buduschey-deyatelnosti

18. Фейгенберг И. М. Вероятностное прогнозирование в деятельности человека / И. М. Фейгенберг. - М. : Изд-во «Наука», 1977. - 387 с.

19. Фетискин Н. П., Козлов В. В., Мануйлов Г. М. Социально-психологическая диагностика развития личности и малых групп / Н. П. Фетискин, В. В. Козлов, Г. М. Мануйлов. - М. : Изд-во Института психотерапии, 2002. - 362 с.

\title{
АНТИЦИПАЦИЯ \\ КАК ОДНО ИЗ УСЛОВИЙ ПРОГНОЗИРОВАНИЯ САМОРАЗВИТИЯ ПЕДАГОГОВ
}

\author{
Хозраткулова Ирина, \\ кандидат педагогических наук, доцент, \\ доиент кафедры педагогики, психологии \\ и менеджмента образования \\ Николаевский областной институт \\ последипломного педагогического образования \\ ул. Адмиралськая, 4-а, 54001, г. Николаев, Украина \\ iryna.khozratkulova@moippo.mk.ua
}

В статье акцентируется внимание на необходимости развития антиципационной состоятельности как одного из основных факторов, который влияет на процесс саморазвития педагогов. Ситуация саморазвития рассматривается как стрессовая.

Феномен стрессоустойчивости представлен как способность личности справляться с трудностями. Обозначена роль стрессоустойчивости для саморазвития и самореализации педагогических кадров. Охарактеризована проблема низкого уровня стрессоустойчивости педагогов как серьезное препятствие на пути профессиональной и личностной мотивачии к саморазвитию.

Уделено внимание важности развития анитиципационных схем, которые помогают активно познать окружающую действительность, понимать новую информацию.

Автор статьи опирается на концептуальные положения позитивной психотерапии, которая исходит из принцииа способности человека ксаморазвитию и гармонии. Для успешного саморазвития личности важно учитывать, что удовлетворение потребности вызывает положительную эмоцию, предоставляет энергии для активизачии волевого усилия.

В статье сделана попытка найти корреляционные связи между уровнем стрессоустойчивости педагога и сформированной состоятельностью к антиципациии.

Охарактеризовано влияние эмоџиональной стабильности на процесс мотивации к саморазвитию и особенности прогнозирования дальнейшего профессионального совершенствования.

Ключевые слова: антиципаџия; педагог; прогнозирование; самомотивация; самопознание; саморазвитие; стрессоустойчивость.

\section{ANTICIPATION AS THE CONDITIONS OF THE TEACHER SELF-DEVELOPMENT}

\author{
Khozratkulova Iryna, \\ Candidate of Pedagogic Science (Ph.D.), Associate Professor \\ Department of pedagogy, psychology \\ and education management \\ Mykolaiv In-Service Teachers Training Institute \\ 4-a Admiralska Street, 54001, Mykolaiv, Ukraine \\ iryna.khozratkulova@moippo.mk.ua
}


The article emphasizes the attention to the necessity of anticipating capacity as a factor, which influences teachers' self-development.

The self-examine is viewed as stress. The phenomenon of stress tolerance is presented as the ability of an individual to cope with the demands placed on a person. The problem of low stress tolerance is a serious obstacle to professional and personal motivation for selfdevelopment.

Attention is paid to the importance of developing anticipation that helps actively learn about the surrounding reality and to understand new information.

According to the author, it is important to study anticipation in human activities.

Various psychological theories of domestic and foreign researchers, which combine the concepts of stress tolerance and anticipation, are considered. The author relies on the concepts of positive psychotherapy, based on the principle of human ability to self-development and harmony. For successful personality self-development, it is important to consider that a satisfied need causes positive emotions, gives energy for activation of volitional effort.

In the article an attempt is made to find correlations between the stress tolerance level of the teacher and the ability to anticipate. The survey results of pedagogical staff reveal the anticipatory ability and they are presented in the article. During the study, significant differences were found in anticipation capacity between the group with high stress tolerance and the group with low stress tolerance. The study confirmed the interconnection between anticipation and stress tolerance of the individual. The author notes the need for psychological support of teachers and emphasizes the implementation of teachers'strategy of positive self-motivation. It can qualitatively affect the effectiveness of the process of self-development of teachers without loss of health.

Keywords: anticipation; self-development; self-knowledge; self-motivation; stress tolerance; teacher.

\section{REFERENCES}

1.Anohin P.K.\& Sudakov, K. V.(Ed.).(1998). Izbrannye trudy: Kibernetika funkcional'nyh sistem [Selected works: Cybernetics of functional systems]. M.: Medicina (rus).

2. Berezhnaja, N. I. (2013). Stressoustojchivost'operativnyh sotrudnikov tamozhennyh organov [Stress resistance of operational staff of customs authorities]. Materialy III Vserossijskogo s'ezda psihologov (25-28 ijunja 2013 g): v 8 t. T. 1. SPb. (rus).

3. Bernshtejn, N. A. (1997.) Ocherki po fiziologii dvizhenij y fiziologii aktivnosti [Sketches on physiology of movements and physiology of activity]. Biomehanika i fiziologija dvizhenij, (pp 300 - 478). M.: Izdatel'stvo «Institut prakticheskoj psihologii»; Voronezh: NPO «Modjek» (rus).

4. Brushlinskij, A. V., Vojavikova, M. I. \& Druzhinin, V. N. (2000). Problema sub'ekta $v$ psihologicheskoj nauke [The subject's problem in psychological science]. M.: Izdatel'stvo «Akademicheskij proekt» (rus).

5. Fejgenberg, I. M. (1977). Verojatnostnoe prognozirovanie v dejatel'nosti cheloveka [Probabilistic forecasting in human activity]. M.: Izd-vo «Nauka» (rus).

6. Fetiskin, N. P., Kozlov, V. V. \& Manujlov, G. M. (2002). Social'no-psihologicheskaja diagnostika razvitija lichnosti i malyh grupp [Socio-psychological diagnosis of the development of personality and small groups]. M.: Izd-vo Instituta Psihoterapii (rus).

7. Kornilova, T. V. (2013). Psihologija neopredelennosti: edinstvo intellektual'nolichnostnoj reguljacii reshenij i vyborov [Psychology of Uncertainty: Unity of Intellectual and Personal Regulation of Decisions and Elections]. Psihologicheskij zhurnal, 34(3), 89-100 (rus).

8. Lomov, B. F. \& Surkov, E. N. (1980). Anticipacija v strukture dejatel'nosti [Anticipation in the structure of activity]. M.: Nauka. (rus).

9. Mendelevich, V. D. \& Granica, A. S. (2013). Prognozirovanie budushhego i mehanizmy nevrogeneza [Prediction of the future and mechanisms of neurogenesis]. Nevrologicheskij vestnik, T. XLV, vyp. 4, 42 (rus). 
10. Mendelevich, V. D. (1998). Klinicheskaja i medicinskaja psihologija. Prakticheskoe rukovodstvo [Clinical and medical psychology. A practical guide]. M.: «MEDpress» (rus). (rus).

11. Najsser, U. (1981). Poznanie i real'nost' [Knowledge and reality]. M.: «Progress»

12. Nichiporenko, N. P. (2007). Prognosticheskaja kompetentnost' v sisteme lichnostnyh svojstv [Prognostic competence in the system of personal properties]. Voprosy psihologii, vyp. 2, 123-130 (rus).

13. Pereguda, S. N. (2015). Nejropsihologicheskij uroven' issledovanija anticipacii $\mathrm{v}$ sovremennoj psihologii [Neuropsychological level of anticipation research in modern psychology]. Klinicheskaja i medicinskaja psihologija: issledovanija, obuchenie, praktika: jelektron. nauch. zhurn, 4 (10). Retrieved from: http://medpsy.ru/climp (rus).

14. Regush L. A. (2003.) Psihologija prognozirovanija: uspehi v poznanii budushhego [Psychology of forecasting: success in cognition of the future]. SPb.: Rech' (rus).

15. Rodzhers, K. (2016). Stanovlenie lichnosti. Vzgljad na psihoterapiju [Personality formation. A look at psychotherapy]. M.: Institut obshhegumanitarnyh issledovanij (rus).

16. Ross, L. \& Nisbett, R. (2000). Chelovek i situacija. Uroki social'noj psihologii [Man and the situation. Lessons in social psychology]. (V. V. Rumynskiy, Trans. from eng.). M.: Aspekt Press (rus).

17. Rybakova, N. A. (2019). Jemocional'naja kompetentnost' pedagoga: sushhnostnaja harakteristika [Emotional competence of a teacher: an essential characteristic]. Pedagogika. Voprosy teorii i praktiki. Tambov: Gramota, T. 4, 190-195. [Elektronnij resurs]. Retrieved from: DOI: https://doi.org/10.30853/pedaqoqy.2019.4.35 (rus).

18. Sergienko, E. A. (2006). Rannee kognitivnoe razvitie: novyj vzgljad [Early cognitive development: a new view]. M.: Izd-vo «Institut psihologii RAN» (rus).

19. Tolstosheina, N. V. (2002). Anticipacija kak odno iz uslovij prognozirovanija, vybora i reguljacii budushhej dejatel'nosti [Anticipation as one of the conditions for forecasting, choosing and regulating future activities.]. Jelektronnyj zhurnal Gaudeamus, 2 (2). Retrieved from: https: //cyberleninka.ru/article/n/antitsipatsiya-kak-odno-iz-usloviy-prognozirovaniyavybora-i-regulyatsii-buduschey-deyatelnosti (rus). 